\title{
Periostracum and fibrous shell microstructure in the unusual Cambrian hyolith Cupitheca
}

\author{
Michael J. VENDRASCO ${ }^{1,2^{*}}$, Antonio G. CHECA ${ }^{1} \&$ Susannah M. PORTER ${ }^{3}$
}

${ }^{1}$ Departamento de Estratigrafía y Paleontología, Universidad de Granada, 18071 Granada, España

2 Present address: Department of Geology, Pasadena City College, 1570 E. Colorado Blvd., Pasadena, California 91106-2003, USA; mvendrasco@pasadena.edu

${ }^{3}$ Earth Research Institute and Department of Earth Science, University of California, Santa Barbara, CA 93106, USA

* Corresponding author

Vendrasco, M.J., Checa, A.G. \& Porter, S.M. 2017. Periostracum and fibrous shell microstructure in the unusual Cambrian hyolith Cupitheca. [Periostraco y microestructura fibrosa de la concha de Cupitheca, un hiolito enigmático del Cámbrico]. Spanish Journal of Palaeontology, 32 (1), 95-108.

\begin{abstract}
Cupitheca is an enigmatic tubular fossil common in early Cambrian deposits worldwide. It has recently been argued to be a hyolith, probably orthothecid. Cupitheca had a dense network of mantle-filled tubules that connected to what we interpret as a continuous organic periostracum. The innermost shell layer consists of horizontal or slightly inclined bundles of fibres elongated along the a-axis and offset from other bundles at aragonitic twin angles, confirming aragonite as the original mineralogy for the shell of Cupitheca. This is a similar shell microstructure to that inferred for Cambrian hyoliths, strengthening the claim that Cupitheca is a hyolith. This shell microstructure of bundled aragonite fibres and the tubule systems can also be seen in many Cambrian molluscs and other lophotrochozoans. In some lineages this shell texture evolved into fracture-resistant crossed lamellar microstructure and in others nacre. These transitions began to occur sometime between the mid-Cambrian and Ordovician, and nacre and crossed lamellar microstructure were the most common constituents of the inner shell layer of molluscs by the middle or late Palaeozoic Era.
\end{abstract}

\section{RESUMEN}

Cupitheca es un fósil tubular enigmático frecuente en depósitos del Cámbrico inferior de todo el mundo. Recientemente se ha asignado a hiolitos, probablemente un Orthothecida. Cupitheca tiene una estructura densa de túbulos, que estaban rellenos por manto y que conectaban con lo que interpretamos como un periostraco orgánico continuo. La capa más interna de la concha consiste en haces de fibras horizontales o ligeramente inclinadas, alargadas según un posible eje cristalográfico a y giradas con respecto a otros haces contiguos a ángulos propios de maclas aragoníticas, lo que confirma la mineralogía original de la concha de Cupitheca como aragonítica. Esta microestructura de concha es similar a la inferida para hiolitos del Cámbrico, lo que refuerza la aserción de que Cupitheca es un hiolito. Esta microestructura a base de haces de fibras aragoníticas y un sistema de túbulos también se puede encontrar en muchos moluscos del Cámbrico y en otros lofotrocozoos. En algunos linajes esta textura de concha evolucionó hacia una microestructura lamelar cruzada, y en otros, hacia nácar, siendo ambas las más resistentes a la fractura. Estas transiciones comenzaron en algún momento entre el Cámbrico medio y el Ordovícico, de modo que 
Keywords: Lamello-fibrillar, crossed lamellar, Parara Limestone, Hyolitha, Problematica, Brachiopoda. el nácar y la microestructura lamelar cruzada fueron las más frecuentes en las capas internas de las conchas de los moluscos ya en el Paleozoico medio o superior.

Palabras clave: Lamelofibrilar, lamelar cruzada, Parara Limestone, Hyolitha, Problemática, Brachiopoda.

\section{INTRODUCTION}

Cupitheca Duan in Xing et al. (1984) is a widespread early Cambrian fossil known from China (Xiao \& Zhou, 1984; Pan et al., 2015; Skovsted et al., 2016), Australia (Bengtson et al., 1990; Skovsted et al., 2016), Antarctica (Wrona, 2003), Spain (Fernández-Remolar, 2005), Canada (Peel, 1987; Skovsted \& Peel, 2007), and Greenland (Malinky \& Skovsted, 2004; Skovsted, 2006). Specimens of Cupitheca are typically tiny (usually no more than $2 \mathrm{~mm}$ in length), straight to slightly curved tubes with a circular or subcircular cross-sectional outline. Bengtson (in Bengtson et al., 1990) provided the best, most complete, description of Cupitheca (as Actinotheca) and noted the unusual flat, rounded shape of the shell termination (Figs 1a, c, f), interpreting it as a transverse septum that formed as the earlier shell segment broke off in a decollation process similar to that of the modern gastropod Caecum (Fretter $\&$ Graham, 1978). Bengtson also noted a concentration of tubules at the transverse wall (see Figs 1d-e), inferring a role of these presumably organic-filled tubes in decollation.

Although Cupitheca had earlier been grouped with hyoliths (e.g. Xiao \& Zhou, 1984), Bengtson (in Bengtson et al., 1990) considered it to be a problematic fossil because there were no clear hyolith features, its unusual pattern of decollation is not known in other hyoliths, and no clear operculum was known. More recently, Skovsted et al. (2016) described opercula from the early Cambrian of Australia and China (see Fig. 1b) that he interpreted to be part of the skeleton of Cupitheca holocyclata based on its consistent co-occurrence, and similarity in size, subcircular outline, and ornament, although the transverse ridges are somewhat more prominent in the opercula than in Cupitheca.

Hyoliths have been argued to represent an extinct class of molluscs (Marek \& Yochelson, 1976; Dzik, 1978) or a separate phylum possibly closely related to sipunculans (Runnegar et al., 1975; Runnegar, 1980, 1996). Recently, Moysiuk et al. (2017) described exceptionally preserved hyoliths from the Burgess Shale and Spence Shale with an apparent lophophore, suggesting that hyoliths may instead be lophophorates.

Herein we describe and interpret details of the shell of Cupitheca, including microstructure, tubules, pathologies, and external ornament. We compare the shell microstructure of Cupitheca with that of other hyoliths as well as molluses, brachiopods and other lophophorates. The shell microstructure of Cupitheca is similar in many ways to that of undisputed Cambrian hyoliths, and also to many helcionellids and unusual Cambrian molluses like Pelagiella and Ocruranus.

\section{MATERIALS AND METHODS}

All the specimens described herein were collected by B. Runnegar and S. Bengtson from the Parara Limestone at Horse Gully, South Australia, University of New England, Armidale localities (UNEL) 1852, 1854, and 1856 (Bengtson et al., 1990). The Parara Limestone at this section contains a diverse fauna, and the presence of the problematic ecdysozoan Stoibostrombus crenulatus and the trilobite Yorkella australis indicates the formation correlates with the Dailyatia odyssei Zone in the Arrowie Basin, Australia, from Stage 3 of Series 2 of the Cambrian (Betts et al., 2016).

Runnegar and Bengtson extracted fossils along with other macerate material from carbonate rock using dilute acetic acid. We sorted the fossils from the macerates, placed them on SEM stubs, and coated the stubs with gold or carbon. Specimens were photographed using: 1) a LEO Gemini 1530 Field Emission SEM with Zeiss Auriga Cross-Beam Station at the Centro de Instrumentación Científica, University of Granada; 2) a Phenom Pro SEM at the Departamento de Estratigrafía y Paleontología, University of Granada; 3) an FEI Sirion model XL30 SEM at the Materials Research Laboratory, University of California at Santa Barbara; or 4) an FEI Quanta 400 Field Emission SEM at the Department of Earth Science, University of California at Santa Barbara. Working distance was typically about $10 \mathrm{~mm}$ and voltages ranged from 3 to $10 \mathrm{kV}$.

All specimens are reposited at the South Australian Museum of Paleontology (SAMP), Adelaide, South Australia. Measurements were made from SEM photographs using Image J (Schindelin et al., 2012). We use descriptive terminology of the fossils as presented by Bengtson (in Bengtson et al., 1990), including 'cylindrical wall' for the tubular shell surface, 'terminal wall' for the apical 
end of the shell, and 'tubules' for the protrusions from the steinkern surface, the inferred mantle projections that in better-preserved specimens connect between the surface of the steinkern and the outer phosphatic sheath that we interpret herein as replaced periostracum.

\section{RESULTS}

\subsection{Shell microstructure}

Fossils of Cupitheca show remarkable variation in features such as degree of shell curvature, length, shell ornament, periostracal thickness, and degree of preservation of tubules. The crystal imprint textures on steinkerns, however, are remarkably consistent, and this along with the fine details of their form and uniqueness compared to other fossils from the Parara Limestone make it clear that these textures reflect original shell microstructure. The shells are interpreted to have been aragonitic, based on angles of offset between adjacent bundles (see below), the fibrous nature of crystallites that are more common with aragonite than calcite, and preservational data. Thin sections of Cupitheca from the Parara Limestone show the wall has been replaced with sparry calcite (Bengtson in Bengtson et al., 1990) whereas fossils from the same assemblage that had original calcite composition show relatively unaltered shell (Runnegar in Bengtson et al., 1990).

Most specimens of Cupitheca from the Parara Limestone show some trace of shell microstructure preserved (Fig. 2). Many of the specimens show elongate, fibre-like impressions that are often sub-parallel to the shell margin (perpendicular to the long-axis of the tube) and that extend for at least tens of micrometres and probably much more. The fibres in one broad region of the inner shell surface often occur at an angle to each other within the same horizontal sub-layer (Figs 2a, c-i). The angles between the fibre bundles are highly variable, but the bestpreserved cases show angles very close to the $60^{\circ}$ and $120^{\circ}$ angles (Fig. 2) expected if fibres in adjacent bundles are aragonitic twins. In some instances the bundles of fibres stacked atop each other have different orientations (Fig. $2 \mathrm{c}$ ), although in other cases vertical tubule fills show borders that match the fibre orientation of the inner shell surface (Figs 2a-b, e-f).

This type of shell microstructure is similar to that named lamello-fibrillar, characterized by successive laminae made up of parallel fibres, with the fibres in different orientations from one stacked layer to the next (Carter et al., 2012). The situation in Cupitheca seems more complex than that, as in at least some cases the fibres in successive horizontal (parallel to shell surface) levels of the shell appear to occur in the same orientation, but neighbouring fibre bundles have a different orientation. These aragonite fibres of the innermost shell layer grew orthogonally to the growth front at the margin (rim) of the shell, interweaving with neighboring fibre bundles.

In many regions of the fossils only one edge of the fibres is clearly preserved (Figs 2e-f). These indicate that the long axis of fibres was slightly tilted relative to the internal surface. In some cases the fibres are tilted down towards the terminal end of the shell, and in others toward the aperture. The aragonitic fibres grew all around the cylindrical wall of Cupitheca, with periodic twinning. They were grouped in sets that had different lateral dips to each other (Fig. 2g), suggesting a loosely-organized precursor to crossed lamellar where bundles of fibres are inclined to the horizontal shell surface, but with vertical growth along the c-axis as opposed to the horizontal growth along the a-axis as in Cupitheca. Watsonella shows a nice transition from the type of shell microstructure of Cupitheca to something close to foliated aragonite (Kouchinsky, 1999), the inferred precursor to nacre (Vendrasco et al., 2011a). In all these shell microstructures (fibrous aragonite as in Cupitheca, crossed lamellar, foliated aragonite, and nacre), the c-axis of aragonite is vertical or more or less so (i.e. orthogonal to shell surface). In fact, in some vetigastropods the microstructure changes through the shell from outer to inner layer from fibrous aragonite to crossed lamellar and to nacre, with the crystallographic orientation of the aragonite crystals staying the same throughout.

The outer shell microstructure of Cupitheca is unclear. Just above the innermost layer characterized by transverse fibre bundles, one specimen (Fig. 2i) shows longitudinal fibres. This is the opposite pattern to that of some Cambrian hyoliths described by Kouchinsky (2000b), with an inner shell layer divided into sublayers where the top part has transverse fibres and the lower part has longitudinal ones. However, in other Cambrian hyoliths the inner shell layer consists of transverse fibres (Kouchinsky, 2000b), as for Cupitheca. Tubule moulds provide some data on microstructures deeper into the shell. These tubule fills (Figs 2a-b, e-f), although partial and only representing a small inner segment of the shell, indicate sub-horizontal fibres in consistent transverse orientations in the shell from the inner shell surface up through a significant thickness of the shell, contrasting with the pattern seen in Figure 2i.

In some cases the shell microstructure imprints are reminiscent of the elongate growth fronts of laminar shell microstructures like foliated aragonite (Figs 2e-f). However, there are no distinct crystal terminations visible along the long axes of the imprints (the lineations are remarkably straight), they are often very closely spaced together, the lineations run parallel to the shell margin as do the more distinct fibres preserved in other specimens, and there is gradation from these linear traces to distinct fibre imprints. The straight edges are consistent with our interpretation of the basic microstructural units as 


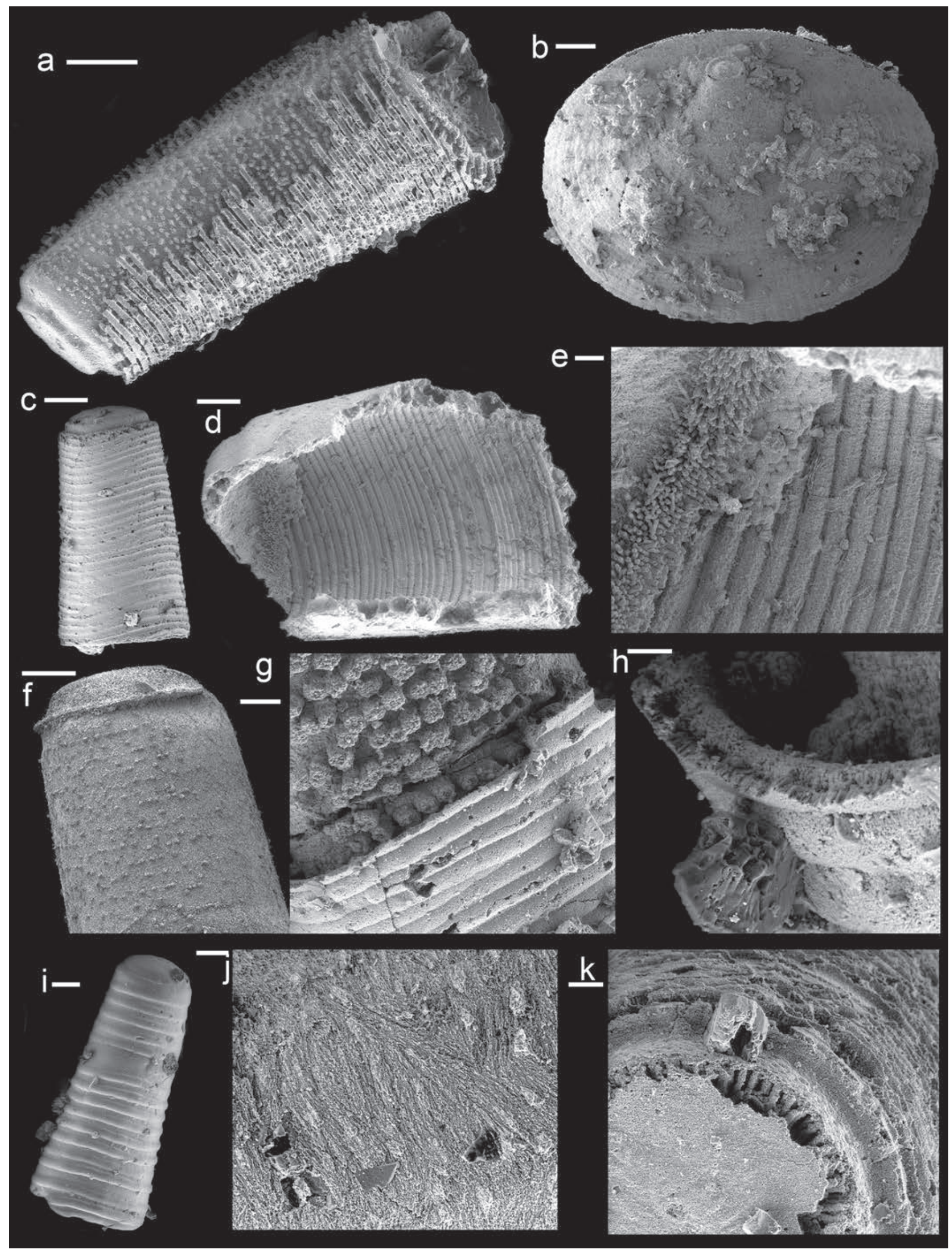


elongate, flat fibres (like very thin blades) of aragonite, as theses straight edges correspond to the lateral margins of the fibres.

\subsection{Periostracum}

The outer wavy layer of Cupitheca is often remarkably well preserved with phosphate (e.g. Figs 1c-e, g-i, 4), in contrast with the underlying shell that was replaced with sparry calcite instead. The consistent thickness and connection to tubules (see below) in the outer wavy layer indicates it is not an external mould. The tiny grains of phosphate that comprise the wavy layer are similar to what Porter (2004) inferred as replaced organic material in the sclerites of halkieriids. The overall form of the wavy layer is similar to that of the periostracum of Neotrigonia (Checa et al., 2014). For these reasons we interpret the outer wavy layer of Cupitheca as representing a phosphatized periostracum possibly homologous to that of molluscs and brachiopods.

\subsection{Tubules}

Specimens of Cupitheca preserve evidence of tubules that extended through the shell, orthogonal to the shell surface. The tubules are preserved in a variety of ways, from tubercles or granules on internal moulds, to fully formed, complete tubes that run from the inner to outer surface of the shell (Figs 1d-g, k, 3, 4a). These tubule casts are in some cases solid but are often hollow (Fig. 3a), indicating they were probably filled with living tissue during life. The tubules have a sub-cylindrical shape and often flare near the external shell surface (Figs 3d-e, j). They align with the valleys on the outer shell surface rather than on the ridges (Fig. 3d).

Views of the inner surface of the outer wavy layer (Figs 1d-e, 3h) show no sign that the tubules extended all the way to the external-most surface of the shell. However they clearly extended nearly to the shell surface (Figs 3d, g-i). Close-up images (Fig. 3d) show a faint boundary between the outer wavy layer and the tubules.
In many specimens tubules may occur in great densities (Fig. 1g), particularly at the terminal wall (Figs 1d-e, 3f-j). Bengtson (in Bengtson et al., 1990) noted the common abundance near the terminal wall, and concluded the tubules there were probably involved in decollation. The striking differences in density and morphology (there is more tapering in the terminal wall canals) of canals in the terminal wall versus elsewhere suggest a different function for the different sets of canals.

\subsection{Pathologies and other anomalies}

Some specimens show growth discontinuities that appear to represent healed scars (Figs $4 \mathrm{~b}-\mathrm{c}, \mathrm{f}$ ). In addition, one specimen shows an unusual pattern of shell microstructure preservation that appears to reflect damage that was translated even to the inner surface of the shell (Figs 4g-h).

Also, dome-shaped protrusions (Figs 4a-b, f) were seen on more than twenty specimens. These do not seem to represent secondary botryoidal coatings of phosphate, as broken protrusions are as thin-walled as the rest of the outer wall (Figs 4d-e). These protrusions are concentrated in certain regions of the external shell surface, including one specimen with the domes arranged in an oval pattern in the middle of the shell (Figs 4a, d). Other specimens show a concentration of these projections in and around apparent healed scars (Fig. 4f), so they may be related to shell damage repair.

\section{DISCUSSION}

\subsection{Structure and formation of the shell of Cupitheca}

We interpret the wavy outer layer of fossils of Cupitheca as a phosphatic replacement of the periostracum. In crosssectional views the structure of the wall can be seen to consist of tiny vertical (orthogonal to shell surface) grains neatly arranged (Fig. 1h). This contrasts with laminar

Figure 1. Morphological features of Cupitheca holocyclata (Bengtson in Bengtson et al., 1990). a) SAMP 54965, composite internal/ external mould with terminal wall at lower left. The internal mould of another terminal wall is visible on the upper right end of the specimen; this may represent a telescoped additional specimen or a preserved decollation event. b) SAMP 54966, inferred operculum of Cupitheca (see also Skovsted et al., 2016). c) SAMP 54967, external view of external mould, terminal wall at top. d) SAMP 54968, internal view of external coating and filling of tubule cluster at terminal wall. Apparent internal mould surface external to this may be due to telescoping specimens. e) close-up of (d). f) SAMP 54969, internal mould with only short length of tubules filled in. g) SAMP 54970, composite internal (top) and external mould, showing both tubule infilling and shell ornament. h) closeup of (g), oblique view of external coating, showing vertical arrangement of phosphate crystals therein. i) SAMP 54971, external mould showing unusually broad ridges. j) SAMP 54972, close-up of internal mould showing multiple orientations to fibre imprints. k) SAMP 54973, view from the terminal wall side of the specimen, showing tubule fillings and external coat. Scale bars: $(\mathbf{a}-\mathbf{d}, \mathbf{f}, \mathbf{i})=100 \mu \mathrm{m} ; \mathbf{( e ,} \mathbf{g})=20 \mu \mathrm{m} ; \mathbf{( h ,} \mathbf{j}-\mathbf{k})=10 \mu \mathrm{m}$. 

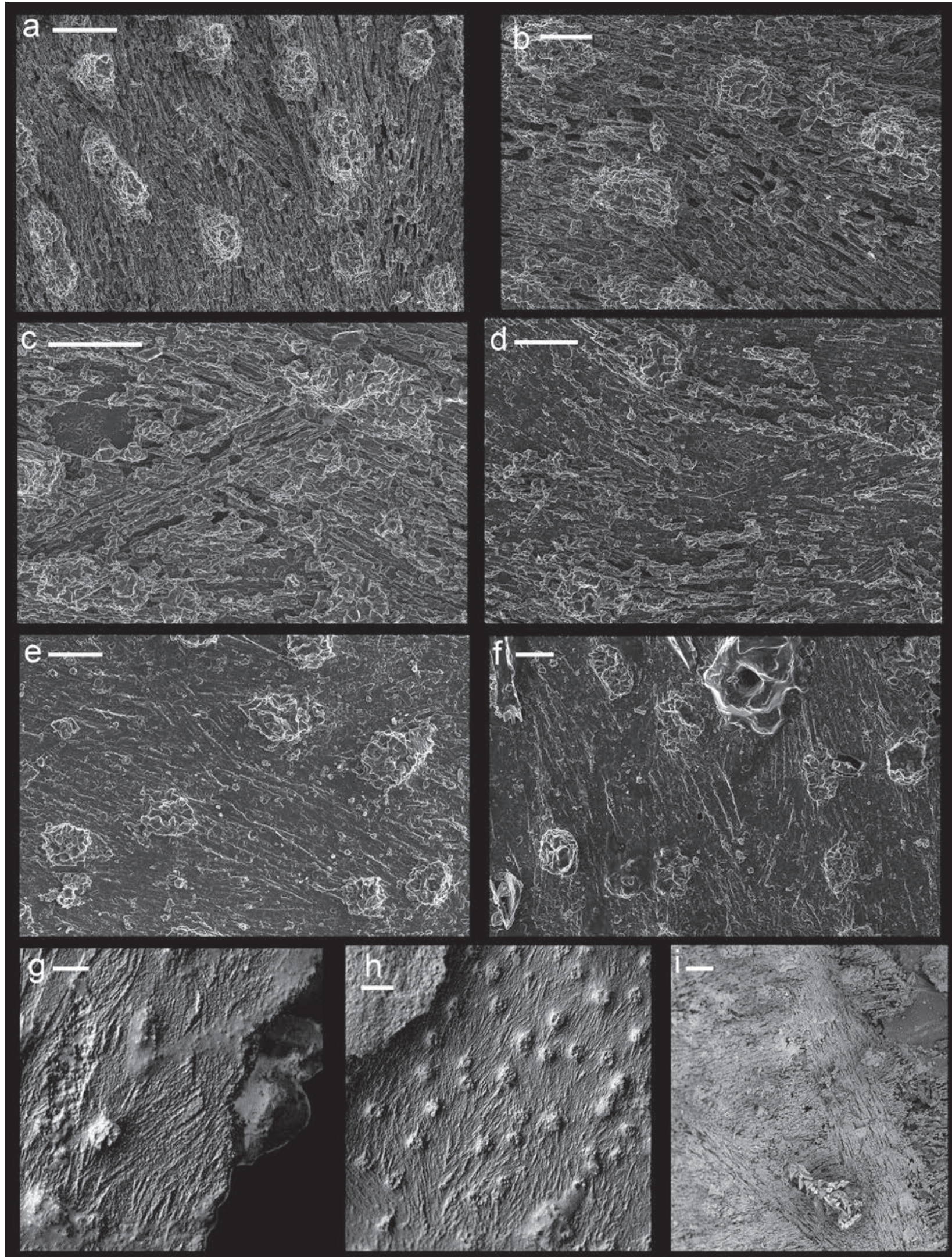

Figure 2. Shell microstructure in Cupitheca holocyclata. (a-d) SAMP 54974. (e-h) SAMP 54975. Views of internal mould surfaces showing partial tubule fills and fibre imprints, as well as partial casts showing shell microstructure details inside the shell. e-h) show straight edges interpreted as fibres tilted along their long axis at a low angle to the inner shell surface. i) SAMP 54976. The bundle on the right is oriented longitudinally, with aperture in the direction towards the lower left corner of the photograph. Scale bars: $(\mathbf{a}, \mathbf{h}-\mathbf{i})=10 \mu \mathrm{m} ;(\mathbf{b}-\mathbf{g})=5 \mu \mathrm{m}$. 
growth expected if the wall instead represents an external coating (mould) of the shell. The thickness of this wall typically ranges from about 1 to 10 microns. The abundant tubules of the shell of Cupitheca open at the base of this wall (Fig. 3d).

The shell of Cupitheca is probably aragonitic, based on preservational patterns, inferred twinning angles, and the fibrous nature of crystallites. We interpret the lineations on the internal moulds as the sides of aragonite fibres elongated along the a-axis. These occur in bundles at various angles to each other, but in general are transverse (run around the shell) in the innermost layer and at least some cases longitudinal just above it (Fig. 2i). The bundles of fibres probably criss-cross each other and occasionally converge in the same horizontal shell layer in nearly horizontal lamellae. The laminar aspect of the inner shell layer can best be seen in Figures 4g-h, showing first order lamellae that consist of bundles of fibres. The aragonite fibres wound around the Cupitheca shell as it grows, with periodic twinning. The fibres may be continuous from old to new shell material, representing very long, spiral elements.

The tubules of Cupitheca are interpreted to represent outpocketings of the mantle epithelium that connected straight through the mineral shell to the base of the periostracum. Besides the concentration at the terminal wall, the abundance of tubules elsewhere on the shell indicates they must have had additional functions besides just for decollation. The tubules of Cupitheca lack the bulbous ends that correspond to the spaces for eyes in the aesthete canal systems of some chitons, but they do flare out somewhat near the shell surface, so they may have had a sensory role, possibly mechanosensory (through cilia) or visual (with simpler photoreceptors, as for most chitons). Their connection to the periostracum may reflect a role in the replenishment of this outer organic shell layer, or the tubules may have otherwise been involved in repairing damage to the shell.

\subsection{Comparison with other hyoliths}

Runnegar et al. (1975) showed evidence that aragonitic crossed-lamellar shell microstructures characterize some hyoliths from the Ordovician and Permian. They inferred an aragonitic composition of the hyolith shell based on preservational patterns. Crossed lamellar texture (bundles of aragonitic fibres highly inclined from the horizontal shell surface, criss-crossing each other) seems clear from their photographs. They described a common shell microstructure in hyoliths where the first order laminae run around the shell in the inner layer and along the shell in the outer layer. Kouchinsky (2000b) described numerous examples of Cambrian hyoliths that show fibre bundles that in the outer layer are longitudinally oriented and dipping slightly toward the apex, and within the inner layer an outer sublayer with fibre bundles transversely oriented (around the shell) and an inner sublayer with fibre bundles longitudinally oriented and at a slight dip to the tangential plane of the inner shell surface.

As with Cupitheca, Cambrian hyoliths show a high density of tubules orthogonal to the shell surface running from the inner shell surface to near the outer shell surface in these Cambrian hyoliths (Kouchinsky, 2000b). As for other hyoliths, Cupitheca probably had an original aragonitic composition.

The broad pattern of the shell in Cupitheca is very similar to that of other hyoliths, strengthening the claim of a hyolith affinity. The inner shell layer of Cupitheca consists of bundles of fibres that differ slightly in orientation but that are more or less tangentially arranged. In one specimen (Fig. 2i), longitudinal fibres can be seen to overlie transverse bundles of fibres in the inner shell layer, a pattern opposite to what Kouchinsky (2000b) found for other Cambrian hyoliths. Nevertheless the tubules in Cupitheca are vertically oriented, densely packed, and run nearly the entire thickness of the shell, as they do in other hyoliths.

\subsection{Comparison with lophophorates}

The shell of Cupitheca shares with brachiopods a dense system of organic-filled tubules that have a predominantly vertical orientation and run from the inner shell surface to near the outer shell surface. The tubules of Cupitheca typically are about 5-10 $\mu \mathrm{m}$ in diameter, and those of craniiform and rhynchonelliform brachiopods are $5-40 \mu \mathrm{m}$ in diameter (Taylor et al., 2010). Tubules in Cambrian hyoliths (Kouchinsky, 2000b) and Cupitheca are straight and unbranching. Caeca typically branch in punctate brachiopods (Williams \& Wright, 1970; Taylor et al., 2010), but in some pitted brachiopods the caeca are unbranching and flare near the outer shell surface (Wright, 1981) as with the tubules of Cupitheca. The Cambrian stem group brachiopods Micrina and Paterimitra also have a shell with tubules that open at both the inner and outer shell surface (Holmer et al., 2008; Skovsted et al., 2009). In these cases the tubes are inferred to have contained setae. The problematic calcite-shelled obolellid brachiopod Mummpikia (see Balthasar, 2008) has the same distribution, size, and orientation of tubules as does Cupitheca. The widespread occurrence of tubules among brachiopods (Williams, 1997a) indicates this feature is probably primitive for the crown group Brachiopoda, and these are probably homologous with similar structures in stem group brachiopods such as Micrina, Paterimitra, and possibly also hyoliths such as Cupitheca.

Brachiopods, like molluscs and Cupitheca, have a distinct outer organic shell layer, typically referred to as 


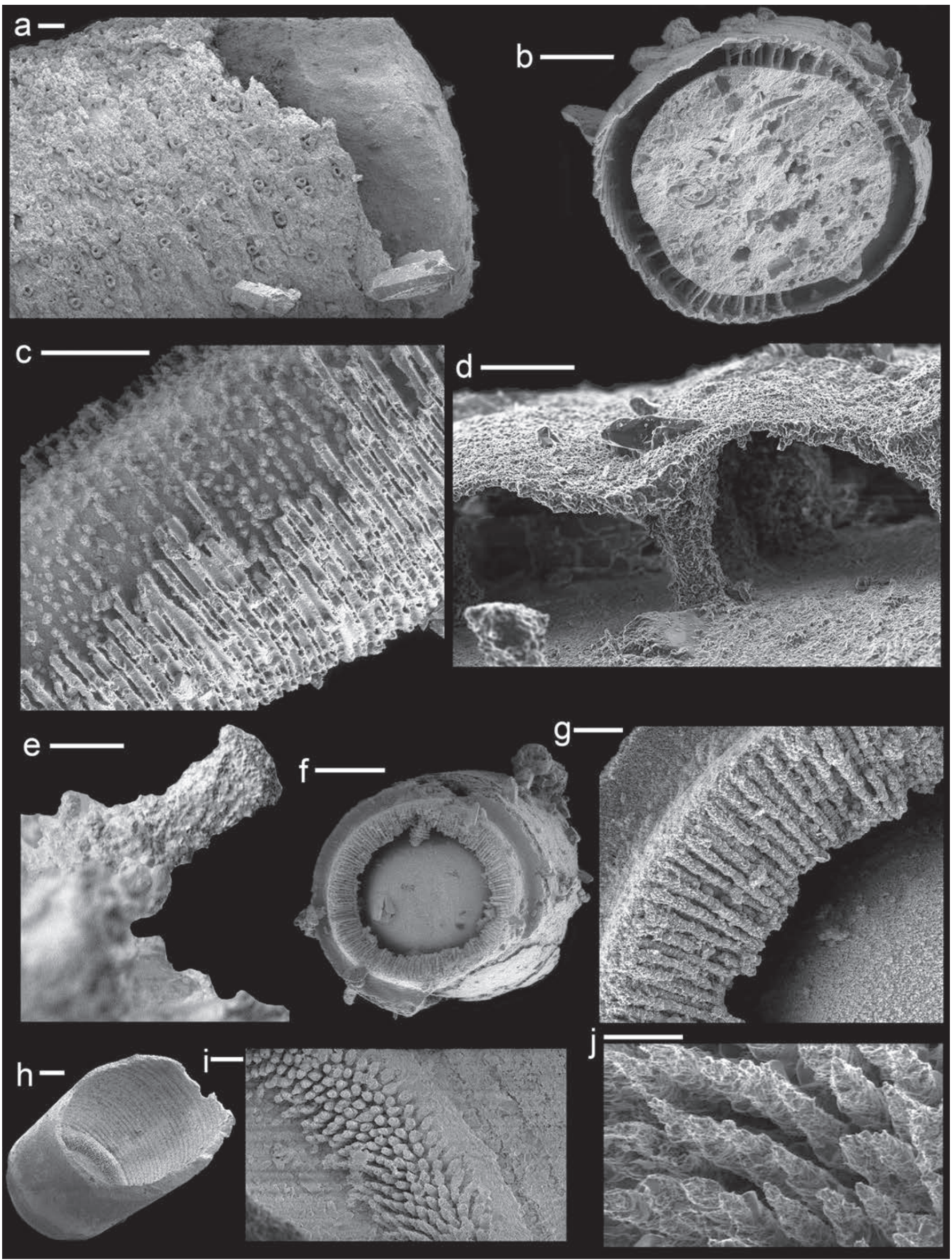


a periostracum. This outermost layer is typically thin in Cupitheca ( 1-10 $\mu \mathrm{m}$ in thickness), consistent with the range in brachiopods; e.g., the periostracum thickness at first crystallization in Calloria is $100 \mathrm{~nm}$, whereas for brachiopods in general, where fully developed, the periostracum can be 5-6 $\mu \mathrm{m}$ thick (Williams, 1997b).

Brachiopods typically have a calcitic or phosphatic shell, although some Palaeozoic trimerellid craniiformean brachiopods may have had an aragonitic shell (Jaanusson, 1966), as possibly did some craniopsids, obolellids, and kutorginids (James \& Klappa, 1983; Geyer, 1994). Bryozoans typically build their skeleton with calcite although sometimes with aragonite (see review of lophophorate biomineralization in Taylor et al., 2010). Cupitheca and other hyoliths, on the other hand, clearly have an aragonitic shell.

\subsection{Comparison with early molluses and other Cambrian taxa}

The hyolith-like configuration of bundles of fibres arranged longitudinally and transversely within the shell can be seen in other Cambrian molluscs, including a number of coiled forms such as a shell from the early Cambrian of Yunnan (Feng et al., 2001), as well as Ocruranus (Vendrasco et al., 2009) and Pelagiella (Runnegar in Bengtson et al., 1990). Pelagiella (Fig. 5) also shares with Cupitheca a bumpy periostracum (see also Runnegar in Bengtson, 1990; fig. 167) made up of apatite crystals elongated orthogonally to the shell surface and that is in some species porous in places (Vendrasco et al., 2010). Similar lamello-fibrillar patterns in the innermost shell layer can be seen in the coiled molluscs Protowenella (Vendrasco et al., 2010) and Aldanella (Kouchinsky, 2000a, personal observation), and Anabarella/Watsonella (Kouchinsky, 1999; Vendrasco et al., 2015). The similarities with Pelagiella are notable, as the latter has been shown to have prominent chaetae (Thomas \& Vinther, 2012), which are more characteristic of brachiopods than molluscs.

The system of tubules in Cupitheca is likewise similar to what occurs in many molluscs. Particularly striking are the similarities with Cambrian helcionelloids, including relatively dense vertical (orthogonal to shell surface) canals that occur without branching throughout most or all of the shell thickness (Parkhaev, 2006; Feng \& Sun, 2006; Vendrasco et al., 2011b). The coiled early Cambrian molluscs Barskovia and Philoxenella show a tubule pattern (Kouchinsky et al., in press) the same as that of Cupitheca. The aesthete channels of modern chitons are more complex, showing horizontal and vertical components with significant branching, and only penetrating the whole shell thickness in some places (Haas \& Kriesten, 1978; Fernandez et al., 2007; Vinther, 2009). Nevertheless chiton aesthete channels typically flare towards the external shell surface as in Cupitheca, and primitive chitons, lacking the articulamentum that typically blocks vertical canals (Hoare, 2009), may have had a simpler arrangement of aesthete canals than do modern forms that better resembles Cupitheca. Tubules also occur in the shells of other modern molluscs, including arcoid and limopsoid bivalves (Waller, 1980; Reindl \& Haszprunar, 1996a), Corbicula (Tan Tiu \& Prezant, 1989), and fissurellid limpets (Reindl \& Haszprunar, 1994). However, differences in fine structure of the pore systems among molluscs that have them led Reindl \& Haszprunar (1996b) to conclude they are not homologous. An extensive canal system also occurs in the sclerites of halkieriids (Vinther, 2009), a taxon suggested to belong to the Mollusca (Vinther et al., 2017). In halkieriid sclerites the canals have a prominently horizontal (parallel to shell surface) orientation, contrasting with the vertical configuration of Cupitheca and others, although in closely related sachitids such as Hippopharangites some of the canals are vertically oriented (Vinther, 2009).

Molluscs, like brachiopods and Cupitheca, have an outermost organic shell layer referred to as the periostracum. The thickness of the periostracum of Cupitheca $(\sim 1 \mu \mathrm{m})$ falls within the range of molluscs. Harper (1997) noted a range in thickness from ultra-thin periostraca in oysters and scallops to thicknesses of 30 $\mu \mathrm{m}$ and more.

\subsection{Tubules and the early lophotrochozoan}

Similar tissue-filled shell pores have been inferred in many Cambrian helcionellids, aculiferans, problematic caps, stem brachiopods, and hyoliths. They maintain prominence in

Figure 3. Tubules in Cupitheca holocyclata. a) SAMP 54977, partial external coating and internal mould of terminal wall (to right). External coating shows the hollow terminations of tubules concentrated along furrows in the external shell. b) SAMP 54978, view from apertural end of specimen showing tubules running vertically all the way through the original shell (dissolved away in this specimen). c) SAMP 54965, composite internal/external mould showing organization of tubules in rows corresponding to the furrows of the outer shell. d) SAMP 54976, close-up of tubule running from surface of internal mould to external coating. e) SAMP 54979, close-up of tubule showing slight flaring towards external surface and possible inclined imprints of shell microstructure. f) SAMP 54980, view of terminal wall region of specimen showing high concentration of tubules in that region. g) close-up of (f). h-j) SAMP 54981, telescoped specimens with external coating and concentrated ring of tubules at apical wall in the innermost specimen. Tubules in this region flare towards the external surface. Scale bars: (a, d-e, $\mathbf{g}, \mathbf{i}-\mathbf{j})=10 \mu \mathrm{m} ; \mathbf{( b - c , ~ f , ~ h ) ~}=100 \mu \mathrm{m}$ 
modern chitons and brachiopods. Shell pores occur in other modern molluscs, although possibly they are not homologous (Reindl \& Haszprunar, 1996b). Such tubules should have provided greater fracture resistance to early shell-breaking predators, as they prevent easy propagation of cracks. These tubules could also have served a sensory and/or secretory role, as with chiton aesthetes.

\subsection{Pathologies and escalation}

Healed shell damage can be seen in some of the betterpreserved specimens of Cupitheca that maintain the outer wall. This indicates the animal was likely under predation pressure, as inferred for early Cambrian molluscs and other taxa (e.g., Conway Morris \& Bengtson, 1994; Whittington, 1985; Skovsted et al., 2007; Vendrasco et al., 2011b). Decollation may have arisen as a response to predation, producing a smaller shell that can move and be hidden more easily than larger forms. The bundles of aragonite fibres occurring in a crossed relationship to each other are reminiscent of the crossed-lamellar shell microstructure of modern molluscs, shown to be resistant to predation (West \& Cohen, 1996).

The dome-shaped projections just underneath the external organic shell surface are a mystery, although their distribution over the surface of some specimens indicate they reflect an aspect of the biology of the animal instead a diagenetic overprint. It is possible that these represent infestation by parasites. They may also represent a growth anomaly for another reason, as smaller versions of these seem to make up the ridges in the periostracal coat. A role in damage repair is another possibility, as these enlarged granules often correlate on the shell surface with healed damage (Fig. 4f).

Kouchinsky (2000b) noted that hyoliths have a high concentration of organic matter within the shell, as their shell tended to remain thin even in larger forms. Cupitheca is no exception. A similar organic-rich, flexible shell was also inferred for Cambrian molluscs like Mellopegma (Vendraco et al., 2011b), and is certainly true for early and modern brachiopods as well. The internal flexibility of the shell afforded by organic layers and inclusions may have provided some resistance to early shell breaking predators. However, as slicing abilities improved among predators of the early Palaeozoic, the need arose for thicker and even stronger, more mineralized shells.

\subsection{The origin of crossed-lamellar shell microstructure}

The evidence for crossed lamellar shell microstructure among Cambrian molluscs is scarce. Runnegar (1985) showed imprints on endolith fillings of fibre bundles with different vertical dip directions (i.e. crossed lamellar structure) in Yuwenia, but otherwise no clear crossed lamellar shell microstructure is known from early molluscs. Ordovician molluses show a preponderance of nacre, but there is a small sample size of species showing original aragonitic shell microstructure. By the middle Palaeozoic crossed lamellar shell microstructure was common in the Mollusca. Among hyoliths the evidence for crossed lamellar shell microstructure from the Cambrian is equivocal (see Runnegar, 1985), but clearly by the Ordovician crossed lamellar microstructure had originated in the Hyolitha and is seen in the later Palaeozoic as well.

\section{CONCLUSIONS}

Cupitheca had a thick organic periostracum connected to the animal's mantle at the shell margin and via abundant tubules running straight through the shell. The periostracum has a radial (orthogonal to shell surface) texture and ranges from about 1 to $10 \mu \mathrm{m}$ or more in thickness. The inner shell layer consists of transverse aragonite fibre bundles at aragonite twin angles to each other and in at least some cases overlain by longitudinal fibre bundles. A similar whole shell microstructure characterizes Cambrian hyoliths in general (Kouchinsky, 2000b), adding support to the hypothesis that Cupitheca is a hyolith. In Ordovician and Permian hyoliths the shell microstructure appears to be crossed lamellar with high angles of dip to the first-order lamellae (Runnegar et al., 1975). Hyoliths independently evolved crossed lamellar shell microstructure with molluscs during the Cambrian-Ordovician. If hyoliths are lophophorates, then this shows one more similarity (crossed-lamellar shell microstructure) in the shells of molluses and lophophorates (see also Carter, 1979, and Vendrasco et al, 2011b). The shell microstructure described as 'lamello-fibrillar' in Cambrian molluscs and other lophotrochozoans may in many cases be the same as that in Cupitheca, and thus a precursor to crossed lamellar shell microstructure may have been widespread during the Cambrian radiation. By the end of the Great Ordovician Biodiversification Event nacre was common in the Mollusca and crossed lamellar had originated among hyoliths and probably also molluscs. Nacre and crossed lamellar are the two shell microstructures most resistant to shell breakage, and their abundance at that time reflects the continuing early arms race between predator and prey. 


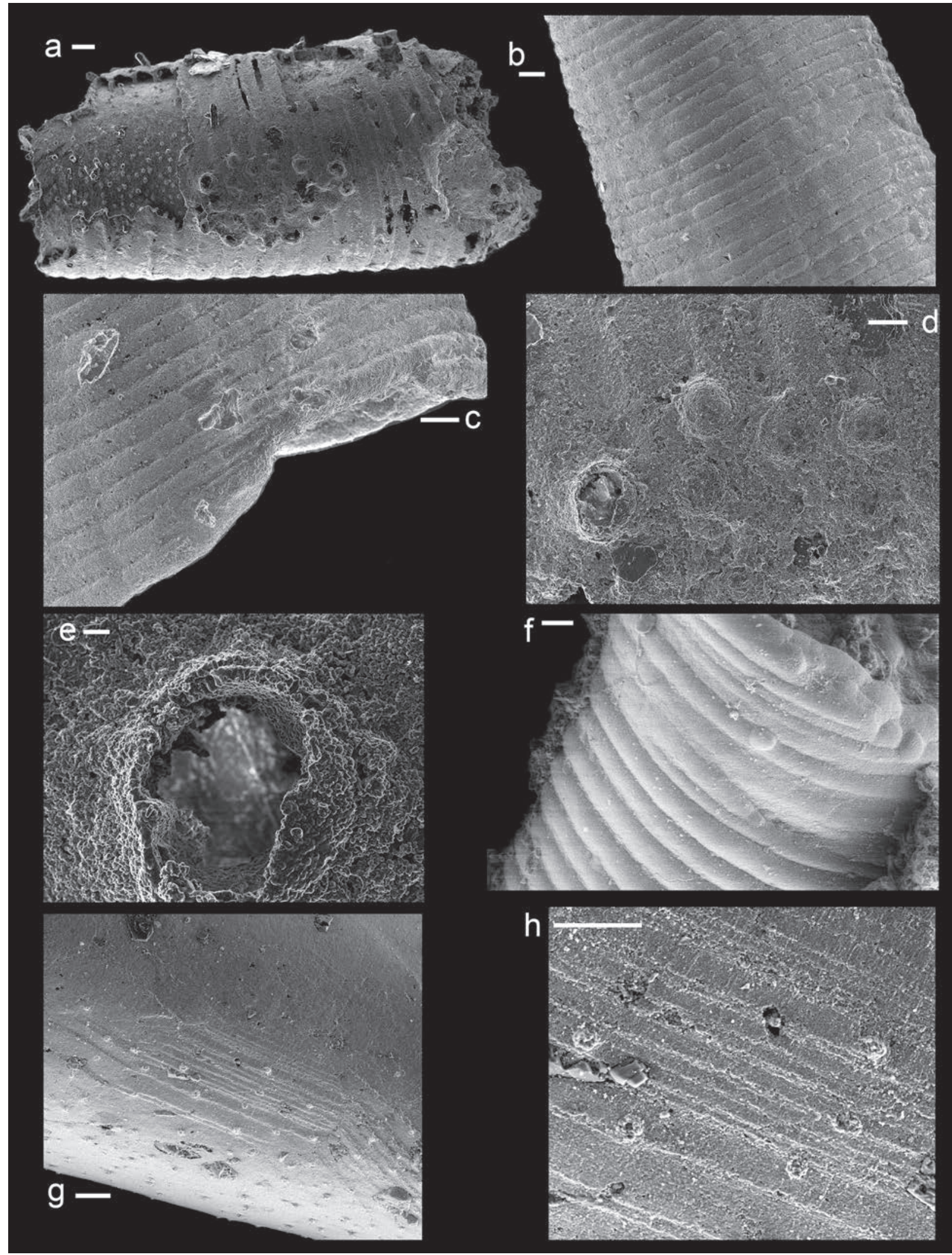

Figure 4. Unusual surface ornament and pathologies in Cupitheca holocylata. (a, d-e) SAMP 54976, composite internal/external mould showing unusual oval collection of large granules in the shell. b-c) SAMP 54982, large granules more sporadically arranged but nevertheless concentrated along ridges in the original shell; (c) shows possible damage near the aperture. f) SAMP 54983, external mould showing a concentration of granules in a region of healed shell damage. g-h) SAMP 54984, internal mould showing unusual linear imprints, possibly reflecting damage that translated through the entire shell. All scale bars $20 \mu \mathrm{m}$ except in (d) $(10 \mu \mathrm{m})$ and (e) $(1 \mu \mathrm{m})$. 


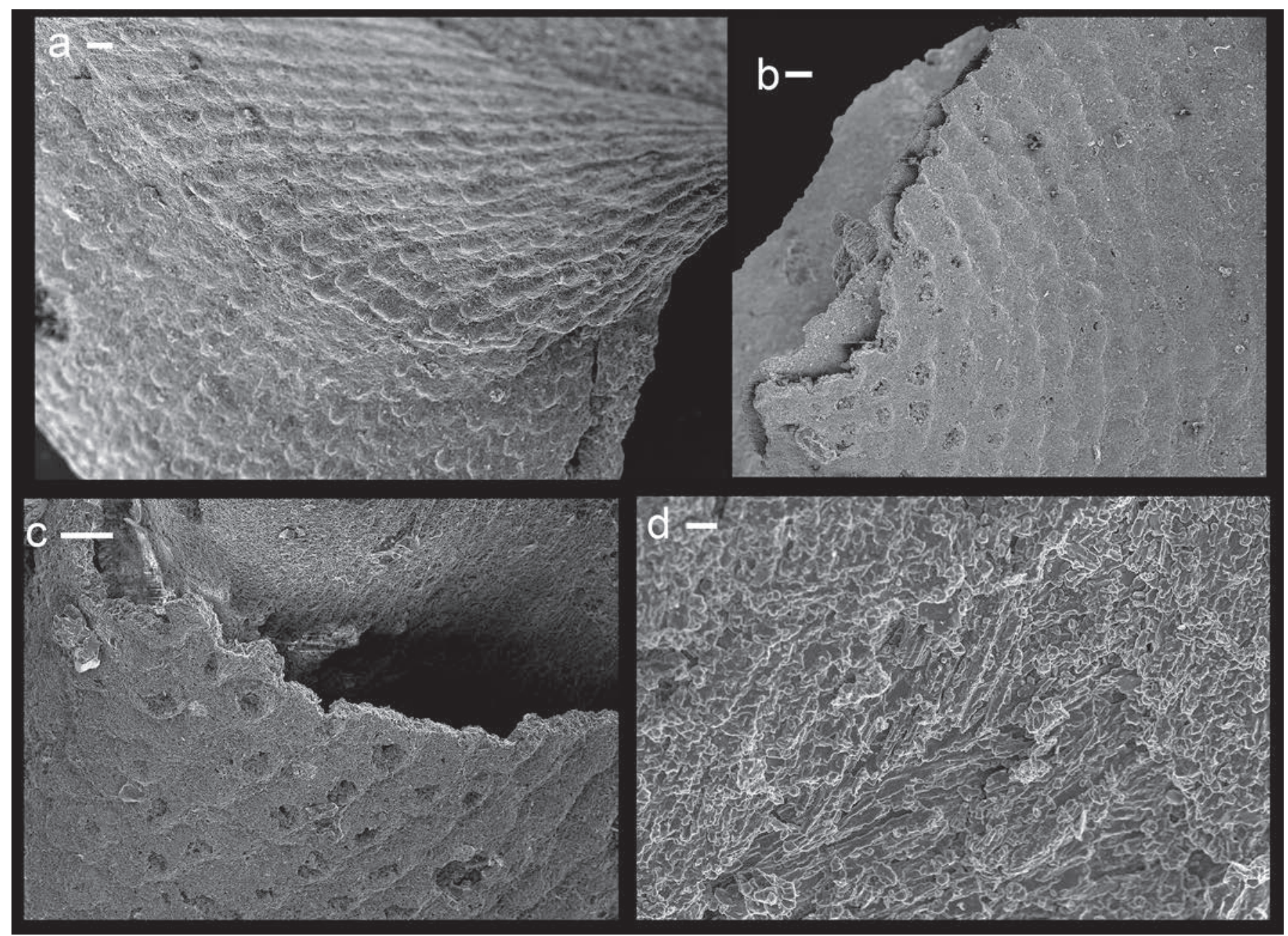

Figure 5. Phosphatized periostracum (a-c) and imprints of fibrous aragonite (d) in Pelagiella subangulata from the Parara Limestone of South Australia, showing an overall shell structure very similar to that of Cupitheca. a) SAMP 54985, phosphatized periostracum is visible throughout the specimen. b) SAMP 54986, phosphatized periostracum and a small section of the steinkern below. c) SAMP 54987, phosphatized periostracum with steinkern surface underneath (at top of photo). d) SAMP 54988, imprint of fibres in the inner shell of Pelagiella. Scale bars: $(\mathbf{a}-\mathbf{c})=10 \mu \mathrm{m} ;(\mathbf{d})=1 \mu \mathrm{m}$.

\section{ACKNOWLEDGEMENTS}

We are grateful to reviewers Christian Skovsted and Guoxiang Li for pointing out errors and for their attention to detail in improving this article. Bruce Runnegar provided unsorted residues from acid maceration. Jenn Osborne and Chris Emerling prepared some of the SEM stubs and took some of the SEM photographs shown herein. John Moore provided good input. MJV thanks the members of the Departamento de Estratigrafía y Paleontología for assistance. This project was funded by a Marie Curie Postdoctoral Fellowship (IIF 301668) from the European Commission and grant CGL2013-48247-P from the Spanish Ministerio de Ciencia e Innovación. And to end we propose a toast to Don Pasqual, a true gentleman and scholar. Salud!

\section{REFERENCES}

Balthasar, U. 2008. Mummpikia gen. nov. and the origin of calcitic-shelled brachiopods. Palaeontology, 51, 263-279; doi: 10.1111/j.1475-4983.2008.00754.x.

Bengtson, S., Morris, S.C., Cooper, B, Jell, P.A. \& Runnegar, B.N. 1990. Early Cambrian fossils from South Australia. Memoir of the Association of Australasian Paleontologists, 9, 1-364.

Betts, M.J., Patterson, J.R., Jago, J.B., Jacquet, S.M., Skovsted, C.B., Topper, T.P. \& Brock, G.A. 2016. A new lower Cambrian shelly fossil biostratigraphy for South Australia. Gondwana Research, 36, 176-208.

Carter, J.G. 1979. Comparative shell microstructure of the Mollusca, Brachiopoda, and Bryozoa. In: Scanning Electron Microscopy/1979, II (director Johari, O.). Chicago Press Corporation, Chicago, USA, 439-446, 456. 
Carter, J.G., Harries, P.J., Malchus, N., Sartori, A.F., Anderson, L.C., Bieler, R., Bogan, A.E., Coan, E.V., Cope, J.C.W., Cragg, S.M., García-March, J.R., Hylleberg, J., Kelley, P., Kleemann, K., Kř́̌ž, J., McRoberts, C., Mikkelsen, P.M., Pojeta, Jr., J., Tëmkin, I., Yancey, T. \& Zieritz, A. 2012. Illustrated glossary of the Bivalvia. Treatise Online, Part N, Revised, Volume 1, Chapter 31, 48, 1-209.

Checa, A.G., Salas, C., Harper, E.M. \& Bueno-Pérez, J.D. 2014. Early stage biomineralization in the periostracum of the 'living fossil' bivalve Neotrigonia. PLOS One, 9, 1-17; doi: 10.1371/journal.pone.0090033.

Conway Morris, S. \& Bengtson, S. 1994. Cambrian predators: possible evidence from boreholes. Journal of Paleontology, 68, 1-23; doi: 10.1017/S0022336000025567.

Dzik, J. 1978. Larval development of hyolithids. Lethaia, 11, 293-299; doi: 10.1111/j.1502-3931.1978.tb01884.x.

Feng, W. \& Sun, W. 2006. Monoplacophoran Igorella-type pore-channel structures from the Lower Cambrian in China. Materials Science and Engineering C, 26, 699-702; doi: 10.1016/j.msec.2005.09.102.

Feng, W., Mu, X. \& Kouchinsky, A.V. 2001. Hyolith-type microstructure in a mollusc-like fossil from the Early Cambrian of Yunnan, China. Lethaia, 34, 303-308; doi: 10.1111/j.1502-3931.2001.tb00059.x.

Fernandez, C.Z., Vendrasco, M.J. \& Runnegar, B. 2007. Aesthete canal morphology in twelve species of chiton (Polyplacophora). The Veliger, 49, 51-69.

Fernández-Remolar, D.C. 2005. Primer registro de los géneros Actinotheca Xiao y Zou, 1984, y Conotheca Missarzhevsky, 1969, en el Cámbrico inferior de la Península Ibérica. In: La Cooperación Internacional en la Paleontología Española (eds Gámez Vintaned, J.A., Liñan, E. \& Valenzuela Ríos, J.I.). Institución Fernando el Católico, Zaragoza, 71-88.

Fretter, V. \& Graham, A. 1978. The prosobranch molluscs of Britain and Denmark. Part 4 - marine Rissoacea. Journal of Molluscan Studies, Supplement 6, 153-236.

Geyer, G. 1994. A new obolellid brachiopod from the Lower Cambrian of Morocco. Journal of Paleontology, 68, 9951002; doi: 10.1017/S0022336000026603.

Haas, W. \& Kriesten, K. 1978. Die ästheten mit intrapigmentär um Schalenauge von Chiton marmoratus L. (Mollusca: Placophora). Zoomorphologie, 90, 253-268.

Harper, E.M. 1997. The molluscan periostracum: an important constraint in bivalve evolution. Palaeontology, 40, 71-97.

Hoare, R.D. 2009. Aesthete Canals in the Chiton Euleptochiton spatulatus (Polyplacophora, Mollusca) from the Pennsylvanian of Ohio. The Ohio Journal of Science, 109, 48-51.

Holmer, L.E., Skovsted, C.B., Brock, G.A., Valentine, J.L., \& Paterson, J.R. 2008. The early Cambrian tommotiid Micrina, a sessile bivalved stem group brachiopod. Biology Letters, 4, 724-728.

Jaanusson, V. 1966. Fossil brachiopods with probable aragonitic shell. Geologiska Föreningens I Stockholm Förhandlingar, 88, 279-281.

James, N.P. \& Klappa, C.F. 1983. Petrogenesis of Early Cambrian reef limestones, Labrador, Canada.
Journal of Sedimentary Research, 53, 1051-1096; doi: 10.1306/212F831E-2B24-11D7-8648000102C1865D.

Kouchinsky, A. 1999. Shell microstructures of the Early Cambrian Anabarella and Watsonella as new evidence on the origin of the Rostroconchia. Lethaia, 32, 173-180; doi: 10.1111/j.1502-3931.1999.tb00537.x.

Kouchinsky, A. 2000a. Shell microstructures in Early Cambrian molluscs. Acta Palaeontologica Polonica, 45, 119-150.

Kouchinsky, A. 2000b. Skeletal microstructures of hyoliths from the Early Cambrian of Siberia. Alcheringa, 24, 6581; doi: 10.1080/03115510008619525.

Kouchinsky, A., Bengtson, S., Landing, E., Steiner, M., Vendrasco, M. \& Ziegler, K. In press. Terreneuvian stratigraphy and faunas from the Anavar Uplift, Siberia. Acta Palaeontologica Polonica.

Malinky, J.M. \& Skovsted, C.B. 2004. Hyoliths and small shelly fossils from the Lower Cambrian of North-East Greenland. Acta Palaeontologica Polonica, 49, 551-578.

Marek, L. \& Yochelson, E.L. 1976. Aspects of the biology of the Hyolitha (Mollusca). Lethaia, 9, 65-82; doi: 10.1111/j.1502-3931.1976.tb00952.x.

Moysiuk, J., Smith, M.R. \& Caron, J.-B. 2017. Hyoliths are Palaeozoic lophophorates. Nature, 541, 394-397; doi: 10.1038/nature20804.

Pan, B., Miao, L., Yang, H. \& Li, G. 2015. Enigmatic tubular fossil Cupitheca from the lower Cambrian Xinji Formation of Luonan, Shaanxi Province. Acta Micropalaeontologica Sinica, 32, 384-395.

Parkhaev, P.Y. 2006. On the Genus Auricullina Vassiljeva, 1998 and shell pores of the Cambrian helcionelloid mollusks. Paleontological Journal, 40, 20-33; doi: 10.1134/S0031030106010035.

Peel, J.S. 1987. Yochelcionella americana (Mollusca) from the Lower Cambrian of Newfoundland. Canadian Journal of Earth Sciences, 24, 2328-2330; doi: 10.1139/e87-218.

Porter, S. 2004. Halkieriids in Middle Cambrian Phosphatic Limestones from Australia. Journal of Paleontology, 78, 574-590; doi: 10.1666/0022-3360(2004)078<0574:HIM $\mathrm{CPL}>2.0 . \mathrm{CO} ; 2$.

Reindl, S. \& Haszprunar, G. 1994. Light and electron microscopical investigations on shell pores (caeca) of fissurellid limpets. Journal of Zoology, London, 233, 385404; doi: 10.1111/j.1469-7998.1994.tb05272.x.

Reindl, S. \& Haszprunar, G. 1996a. Fine structure of caeca and mantle of arcoid and limopsoid bivalves (Mollusca: Pteriomorpha). The Veliger, 39, 101-116.

Reindl, S. \& Haszprunar, G. 1996b. Shell pores (caeca, aesthetes) of Mollusca: a case of polyphyly. In: Origin and Evolutionary Radiation of the Mollusca (ed. Taylor, J.). Oxford University Press, London, 115-118.

Runnegar, B. 1980. Hyolitha: status of the phylum. Lethaia, 13, 21-25; doi: 10.1111/j.1502-3931.1980.tb01025.x.

Runnegar, B. 1985. Shell microstructures of Cambrian molluscs replicated by phosphate. Alcheringa, 9, 245-257; doi: 10.1080/03115518508618971.

Runnegar, B. 1996. Early evolution of the Mollusca: the fossil record. In: Origin and Evolutionary Radiation of 
the Mollusca (ed. Taylor, J.). Oxford University Press, London, 77-87.

Runnegar, B., Pojeta, J., Morris, N.J., Taylor, J.D., Taylor, M.E. \& McClung, G. 1975. Biology of the Hyolitha. Lethaia, 8, 181-191.

Schindelin, J., Arganda-Carreras, I. \& Frise, E., Kaynig, V., Longair, M., Pietzsch, T., Preibisch, S., Rueden, C., Saalfeld, S., Schmid, B., Tinevez, J.-Y., White, D.J., Hartenstein, V., Eliceiri, K., Tomancak, P. \& Cardona, A. 2012. Fiji: an open-source platform for biological-image analysis. Nature Methods, 9, 676-68; doi: 10.1038/nmeth.2019.

Skovsted, C.B. 2006. Small shelly fauna from the upper Lower Cambrian Bastion and Ella Island Formations, North-East Greenland. Journal of Paleontology, 80, 1087-1112; doi: 10.1666/0022-3360(2006)80[1087:SSFFTU]2.0.CO;2.

Skovsted, C.B. \& Peel, J.S. 2007. Small shelly fossils from the argillaceous facies of the Lower Cambrian Forteau Formation of western Newfoundland. Acta Palaeontologica Polonica, 52, 729-748.

Skovsted, C.B., Brock, G.A., Lindström, A., Peel, J.S., Paterson, J.R. \& Fuller, M.K. 2007. Early Cambrian record of failed durophagy and shell repair in an epibenthic mollusc. Biological Letters, 3, 314-317; doi: 10.1098/ rsbl.2007.0006.

Skovsted, C.B., Holmer, L.E., Larsson, C.M., Högström, A.E.S., Brock, G.A., Topper, T.P., Balthasar, U., Petterson Stolk, S. \& Paterson J.R. 2009. The scleritome of Paterimitra: an Early Cambrian stem group brachiopod from South Australia. Proceedings of the Royal Society B, 276, 1651-1656; doi: 10.1098/rspb.2008.1655.

Skovsted, C.B., Pan, B., Topper, T.P., Betts, M.J., Li, G. \& Brock, G.A. 2016. The operculum and mode of life of the lower Cambrian hyolith Cupitheca from South Australia and North China. Palaeogeography, Palaeoclimatology, Palaeoecology, 443, 123-130; doi: 10.1016/j.palaeo.2015.11.042.

Tan Tiu, A. \& Prezant, R.S. 1989. Shell tubules in Corbicula fluminea Bivalvia: Heterodonta): functional morphology and microstructure. The Nautilus, 103, 36-39.

Taylor, P.D., Vinn, O. \& Wilson, M.A. 2010. Evolution of biomineralization in 'lophophorates'. Special Papers in Palaeontology, 84, 317-333; doi: 10.1111/j.14754983.2010.00985.x.

Thomas, R.D.K. \& Vinther, J. 2012. Implications of the occurrence of paired anterior chaetae in the late early Cambrian mollusc Pelagiella from the Kinzers Formation of Pennsylvania for relationships among taxa and early evolution of the Mollusca. Geological Society of America Abstracts with Programs, 44, 326.

Vendrasco, M.J., Li, G., Porter, S.M. \& Fernandez, C.Z. 2009. New data on the enigmatic Ocruranus-Eohalobia group of Early Cambrian small skeletal fossils. Palaeontology, 52, 1373-1396; doi: 10.1111/j.1475-4983.2009.00913.x.

Vendrasco, M.J, Porter, S.M., Kouchinsky, A., Li, G. \& Fernandez, C.Z. 2010. New data on molluses and their shell microstructures from the middle Cambrian Gowers Formation, Australia. Palaeontology, 53, 97-135; doi: 10.1111/j.1475-4983.2009.00922.x.
Vendrasco, M.J., Kouchinsky, A.V. \& Checa, A.G. 2011a. Shell microstructure of the early bivalve Pojetaia and the independent origin of nacre within the Mollusca. Palaeontology, 54, 825-850; doi: 10.1111/j.14754983.2011.01056.x.

Vendrasco, M.J., Kouchinsky, A.V., Porter, S.M. \& Fernandez, C.Z. 2011b. Phylogeny and escalation in Mellopegma and other Cambrian molluscs. Palaeontologia Electronica, $14,44 \mathrm{p}$.

Vendrasco, M.J., Rodríguez-Navarro, A.B., Checa, A.G., Devaere, L. \& Porter, S.M. 2015. To infer the early evolution of mollusc shell microstructures. Key Engineering Materials, 672, 113-133; doi: 10.4028/www.scientific.net/ KEM.672.113.

Vinther, J. 2009. The canal system in sclerites of lower Cambrian Sinosachites (Halkieriidae: Sachitida): significance for the molluscan affinities of the sachitids. Palaeontology, 52, 689-712; doi: 10.1111/j.1475-4983.2009.00881.x.

Vinther, J., Parry, L., Briggs, D.E.G. \& Van Roy, P. 2017. Ancestral morphology of crown-group molluscs revealed by a new Ordovician stem aculiferan. Nature, 542, 471474; doi: 10.1038/nature21055.

Waller, T.R. 1980. Scanning electron microscopy of shell and mantle in the Order Arcoida (Mollusca: Bivalvia). Smithsonian Contributions to Zoology, 313, 1-58; doi: 10.5479/si.00810282.313.

West, K. \& Cohen, A. 1996. Shell microstructure of gastropods from Lake Tanganyika, Africa: adaptation, convergent evolution, and escalation. Evolution, 50, 672-681; doi: $10.2307 / 2410840$.

Whittington, H.B. 1985. The Burgess Shale. Yale University Press, New Haven, Connecticut.

Williams, A. 1997a. Shell structure. In: Treatise on Invertebrate Paleontology, Part H, Brachiopoda (Revised 1: Introduction) (ed. Kaesler, R.L.). The Geological Society of American and the University of Kansas, Boulder, Colorado.

Williams, A. 1997b. Brachiopoda: introduction and integumentary system. In: Microscopic Anatomy of Invertebrates, Volume 13: Lophophorates, Entoprocta, and Cycliophora (eds Harrison, F.W. \& Woollacott, R.M.). Wiley-Liss, New York, pp. 237-296.

Williams, A. \& Wright, A.D. 1970. Shell structure of the Craniacea and other calcareous inarticulate Brachiopoda. Special Papers in Palaeontology, 7, 1-51.

Wright, A.D. 1981. The external surface of Dictyonella and of other pitted brachiopods. Palaeontology, 24, 443-481.

Wrona, R. 2003. Early Cambrian molluscs from glacial erratics of King George Island, West Antarctica. Polish Polar Research, 24, 181-216.

Xiao, L. \& Zhou, B. 1984. Early Cambrian Hyolitha from Huainan and Huoqiu County in Anhui Province. Professional Papers in Stratigraphy and Palaeontology, 13, 141-151.

Xing, Y., Ding, Q., Luo, H., Gui, H. \& Wang, Y. 1984. The Sinian-Cambrian boundary of China. Bulletin of the Institute of Geology, Chinese Academy of Geological Sciences, 10, 1-262. 